\title{
Socioeconomic and institutional factors influencing adoption of conservation farming by vulnerable households in Zimbabwe
}

\author{
Kizito Mazvimavi ${ }^{*}$, Steve Twomlow ${ }^{1}$ \\ International Crops Research Institute for the Semi-Arid Tropics, P.O. Box 776, Bulawayo, Zimbabwe
}

\section{A R T I C L E I N F O}

\section{Article history:}

Received 23 April 2008

Received in revised form 12 February 2009 Accepted 23 February 2009

Available online $\mathrm{xxxx}$

\section{Keywords:}

Conservation farming

Adoption intensity

Tobit model

Extension

Labor availability

\begin{abstract}
A B S T R A C T
Since 2004, there has been a series of initiatives in Zimbabwe to promote conservation agriculture (CA) through various donor-funded relief initiatives with the aim of improving crop production among vulnerable farmers. In April 2007, the International Crops Research Institute for the Semi-Arid Tropics (ICRISAT) implemented a survey to collect data from 12 districts and 232 households that had been practicing hand hoe-based conservation farming (CF) for at least one prior season with extension and input support from non-governmental organizations. This study was undertaken to better understand the household and institutional factors that influence CF adoption patterns among the beneficiaries of these relief initiatives. Results from the study show that institutional support and agro-ecological location have strong statistical influence on the adoption intensity of different CF components. Besides the practice of preparing basins, at least $70 \%$ of the households had also adopted the following components of CF: manure application in the planting basin, topdressing with nitrogen fertilizer at the 5-6 leaf stage of the cereal crop, and timely post-planting weeding. Household labor availability and impacts of HIV/AIDS did not limit the intensity of adoption of CF. An enterprise budget analysis proved that because of the significant yield gains realized with $\mathrm{CF}$, the technology is more viable than conventional tillage practices of broadcasting manure and overall spring tillage on the day of planting. The increased profitability in adopting CF was also reflected in steady increases in the area each household committed to CF from an average area of $1450 \mathrm{~m}^{2}$ in 2004 to more than $2000 \mathrm{~m}^{2}$ in 2007.
\end{abstract}

๑ 2009 Elsevier Ltd. All rights reserved.

\section{Introduction}

Since 2004, there has been a series of initiatives in Zimbabwe to promote conservation agriculture (CA) through various donorfunded relief and recovery programs with the aim of improving crop production among vulnerable smallholder farmers. The most common CA package being promoted is a hand hoe-based system that focuses on the creation of planting basins in the dry season, locally referred to as 'conservation farming' (CF) (Protracted Relief Program, 2005; Hove and Twomlow, 2007).

The terms 'conservation agriculture' and 'conservation farming' have often been used interchangeably in various literatures. For the purposes of this article, however, the two are different. In this article, we have adopted the terminology as defined by the United $\mathrm{Na}$ tion's Food and Agriculture Organization (FAO) Conservation Agriculture Task Force for Zimbabwe (Twomlow et al., 2008a). Conservation agriculture is a broad term, which encompasses activities such as minimum and zero tillage, tractor powered, animal pow-

\footnotetext{
* Corresponding author. Tel.: +26383 8311/4; fax: +263838307.

E-mail addresses: k.mazvimavi@cgiar.org (K. Mazvimavi), stephen.twomlow@ unep.org (S. Twomlow).

1 Present address: Division of GEF Coordination, United Nations Environmental Programme, P.O. Box 47074 (00100), Nairobi, Kenya.
}

ered and manual methods, integrated pest management, integrated soil and water management, and includes CF. It is generally defined as any tillage sequence that minimizes or reduces the loss of soil and water and achieves at least 30\% soil cover using crop residues. Conservation farming is CA practiced by smallholder farmers using small farm implements such as the hand hoe to create planting basins. It is actually a modification of the traditional pit systems once common in southern Africa. It is also a variation on the Zai pit system from West Africa, which may also be considered a CF technology (Mando et al., 2006). The Zai system works by a combination of water harvesting in wide shallow pits $(0.6 \mathrm{~m}$ by $0.6 \mathrm{~m}$ by $0.3 \mathrm{~m})$ and concentrating available fertility amendments, such as animal manure and leaves in the pit. Typically, some 10,000 Zai are prepared per ha, but the number actually dug in any given season is restricted by the availability of fertility amendments.

In 2004, the International Crops Research Institute for the SemiArid Tropics (ICRISAT) began providing technical assistance to more than 10 non-governmental organizations (NGOs) under the United Kingdom's Department for International Development (DFID) Protracted Relief Programme (PRP) to promote CF across 13 districts in the Semi-Arid areas of Zimbabwe (www.prpzim.info/). As a result, farmers are showing a growing interest in $\mathrm{CF}$ and reporting yield gains ranging from 10 to more than $200 \%$ as compared to the traditional practice of overall spring plowing and planting (Hove and 
Box 1 Components of CF practices promoted in Zimbabwe (adapted from PRP (2005))

(1) Winter weeding: The first step in preparing a field using CF methods is to remove all weeds. This should be done soon after harvesting in May/June. Weeding is done using implements such as hand hoes and machetes that disturb the soil as little as possible. The importance of weeding before land preparation is to ensure that the plot is weed-free at basin preparation and also to prevent the dispersal of weed seeds.

(2) Digging planting basins: Planting basins are holes dug in a weed-free field into which a crop is planted and are prepared in the dry season from July to October. Recommended dimensions are $15 \mathrm{~cm}$ width, $15 \mathrm{~cm}$ depth, and $15 \mathrm{~cm}$ length. The basins enable the farmer to plant the crop after the first effective rains when the basins have captured rainwater and drained naturally. Seeds are placed in each basin at the appropriate seeding rate and covered with clod-free soil. The advantage of using basins is that they enhance the capture of water from the first rains of the wet season and enable precision application of both organic and inorganic fertilizer as it is applied directly into the pit and not broadcast.

(3) Application of crop residues: Crop residues are applied on the soil surface in the dry season, soon after harvesting. The residues must provide at least $30 \%$ soil cover. The mulch buffers the soil against extreme temperatures (thereby reducing soil evaporation), cushions the soil against traffic, and suppresses weeds through shading and improves soil fertility.

(4) Application of manure: Fertility amendments are applied soon after land preparation in the dry season. In CF, the application of both organic and inorganic fertilizers is recommended as they complement each other. Organic fertilizers such as manure and/or composts are applied at a rate of at least a handful per planting basin. More can be used in wetter areas.

(5) Application of basal fertilizer: Inorganic basal fertilizer is also applied soon after land preparation before the onset of the rains. One level beer bottle cap is applied per planting basin and covered lightly with clod-free soil. Application rates can be increased in wetter areas and may depend on crop types.

(6) Application of topdressing: Nitrogen fertilizer is applied to crops between 3 and 6 weeks after crop emergence soon after the first weeding at a rate of one level beer bottle cap per basin. Application is done on moist soils. Precision application ensures that the nutrients are available where they are needed.

(7) Timely weeding: In conventional tillage systems, farmers plow/cultivate repeatedly in order to suppress weeds. With reduced tillage, weeds can be a problem requiring more effort initially. One strategy is to weed in a timely manner (i.e., when the weeds are still small) preventing the weeds from setting seed. Timely weeding in combination with mulch should eventually lead to effective weed control.

(8) Crop rotation: Rotating crops is one of the key principles of $\mathrm{CF}$. Cereal/legume rotations are desirable because there is optimum plant nutrient use by synergy between different crop types. The advantages of crop rotation include improvement of soil fertility, controlling weeds, pests and diseases, and producing different types of outputs, which reduce the risk of total crop failure in cases of drought and disease outbreaks.

Source: Protracted Relief Program (2005).
Twomlow, 2007; Twomlow et al., 2008a). Despite the fact that these yield increases depend on the level of experience of the farm household and seasonal rainfall, a growing number of farmers are voluntarily taking up various parts of the CF practices. Box 1 summarizes key components of $\mathrm{CF}$ practices promoted in Zimbabwe (Protracted Relief Program, 2005) and will be the basis for adoption measurement in this article.

Over the past decade, there has been a growing advocacy that CA is important in establishing household food security for poorer farmers in sub-Saharan Africa (SSA) and Asia, an approach that can help attain the United Nations' Millennium Development Goal on food security (Hobbs, 2007; Hobbs et al., 2007). Despite this growing interest in CA, certain sources such as Gowing and Palmer (2008) argue that the technology transfer effort in SSA is still limited to on-farm demonstration trials and that farmers are not adopting CA practices. This is despite years of research and development investment in SSA (Twomlow et al., 2006; Lal, 2007; Rockstrom et al., 2007) and is in direct contrast to the mounting evidence of impact from South America and parts of Asia (Derpsch, 2005; Hobbs et al., 2007).

Yet, the picture is not as gloomy as Gowing and Palmer (2008) paint and much can be attributed to a lack of internationally published work on CA adoption trends among poor farmers in Africa. For example, Zambia has had an active Conservation Farming Unit (CFU) since the mid 1990s, which is currently working with more than 50,000 smallholder farmers (Haggblade and Tembo, 2003; www.conservationagriculture.net). Since 2003 lessons from Zambia's CFU in terms of training and support approaches have been transferred to Zimbabwe via relief programs, where there has been an active agenda of promoting the principles of CA (Twomlow et al., 2008a). This has resulted in Zambia and Zimbabwe being considered leading spots for CA in southern Africa.

There are two parts to a farmer's decision to implement $\mathrm{CF}$ techniques: one is the decision of whether or not to adopt the technology and the second is to determine the level or intensity of technology use (Sall et al., 2000; Brett, 2004). In Zimbabwe, the decision to adopt CF practices was not, in most cases, voluntary. Farmers who first participated in CF promotion were selected by NGOs as vulnerable households facing production constraints. Vulnerable households are defined as families that face difficulties in meeting their basic livelihood needs. This definition has been extended by relief agencies in Zimbabwe to include households affected by the HIV/AIDS epidemic. These households were provided with agricultural inputs and appropriate extension support as incentives to adopt the CF technology (Twomlow et al., 2008a). After a period of learning the new CF technology, vulnerable households, including some spontaneous adopters, will experience variations in the level of use of the new farming practice.

There is mounting evidence that less vulnerable households are also taking up aspects of the package with no external incentives. There has been some spontaneous adoption, mostly from farmers learning the technology from their neighbors. At the same time there has also been some dis-adoption by farmers who originally participated in the CF promotions, but subsequently opted out due to various reasons. Among the farmers who continue to practice $\mathrm{CF}$, many have modified the package and generally adopted some components of the technology while leaving out other recommended practices.

Recent evaluations suggest an incremental uptake of the various components of the CF technology (Mazvimavi et al., 2008). However, there is a need to better understand why some farmers adopt the complete package and others only partly adopt CF. It is critical to understand both farm and farmer characteristics that are likely to affect the level of adoption of this technology. This study was motivated by the need to identify the socioeconomic and institutional factors that influence the adoption of CF technol- 
ogies promoted by different relief initiatives in Zimbabwe, and draw lessons that might be of value for other relief and development initiatives in Africa. In fact, few if any studies have been undertaken in the smallholder sector to assess the key factors that influence the uptake of soil and water management interventions by smallholder farmers, including CF technology (Rusike et al., 2006).

\section{Methodology}

\subsection{Study sample}

In April 2007, ICRISAT undertook a national survey that included seven of 13 districts in the south where the Institute has been facilitating the promotion of $\mathrm{CF}$, and five in the north where NGOs conducted the promotion on their own. The sample included areas across different agro-ecological regions (Table 1), known as Natural Regions in Zimbabwe (Vincent and Thomas, 1960) to capture spatial variability in CF practice. Data was collected through formal interviews and 21 focus group discussions. The questionnaires covered 232 households. These households were purposely selected based on experience with CF practices (at least 2-3 years of practice), and at least half of the sample per district to include households with severe labor constraints, for example, those affected by HIV/AIDS or female-headed households. In addition, in every district sub-sample, we sought to include some households that voluntarily adopted CF and had 2-3 years experience; these households were referred to as spontaneous adopters. Focus group discussions were held with farmers known to have better-thanaverage knowledge of CF practices, and in each district these included individuals who had been practicing $\mathrm{CF}$ for longer periods of time.

In nine of the 12 sampled districts the sampling frame specifically targeted households that were practicing CF in the 2006/07 season and each household in these nine districts had planting basins established in their fields. In the remaining three districts, 17 out of the 60 households interviewed did not practice CF in 2006/ 07 , because either the NGO responsible for introducing CF was no longer operational in the area or the farmers had simply disadopted the practice, opting instead for conventional animal draft tillage. The selection of households with more experience in CF will enable the capture of longitudinal variability with the technology.

\section{Table 1}

Sample of number of households interviewed and focus group discussions carried out in March and April 2007 from selected districts in Zimbabwe.

\begin{tabular}{llll}
\hline District & Natural region & $\begin{array}{l}\text { i } \\
\text { interviews }\end{array}$ & Focus group discussions \\
\hline Bindura & II & 20 & 2 \\
Chirumhanzu & III & 16 & 1 \\
Chivi & V & 20 & 2 \\
Gokwe South & III & 18 & 2 \\
Hwange & IV/V & 20 & 2 \\
Insiza & IV & 20 & 2 \\
Mangwe & IV/V & 20 & 1 \\
Masvingo & III & 22 & 2 \\
Mt Darwin & II & 16 & 1 \\
Murehwa & II & 20 & 2 \\
Nkayi & IV & 20 & 2 \\
Nyanga & V & 20 & 2 \\
Total & & $\mathbf{2 3 2}$ & $\mathbf{2 1}$ \\
\hline
\end{tabular}

a Zimbabwe is divided into five agro-ecological regions, also known as Natura Regions I-V. Natural Regions I and II receive the highest rainfall (at least $750 \mathrm{~mm}$ per annum) and are suitable for intensive farming. Natural Region III receives moderate rainfall (650-800 mm per annum), and Natural Regions IV and V have fairly low annual rainfall (450-650 mm per annum) and are suitable for extensive farming. Adapted from Vincent and Thomas (1960).
However, it should be noted that 2-3 years is still a short period from which to draw strong conclusions on CF adoption trends and it is planned within PRP Phase II to revisit the same farmers in future seasons to understand more on the dynamics of $\mathrm{CF}$ practices.

Farmers were asked about current CF practices such as winter weeding, management of crop residues, timely weeding, and crop rotation. If farmers were not practicing one of the management options they were asked why this was the case. Other questions related to weeding practices, labor allocation, time of planting, crop rotation and residue management.

After the household interviews a focus group discussion was held to collect supplementary qualitative information on adoption constraints and impacts of CF in the community. The questionnaire interviews were carried out first to avoid any bias that might arise from influences by other farmers who participated in group discussions.

\subsection{Yield determination}

During the field visits the total area of the CF plot was measured and an area of at least $50 \times 20 \mathrm{~m}$ was demarcated on the CF plot and on an adjacent farmer practice plot for yield estimates to be made at harvest. Larger plots were demarcated when the whole CF plot area was greater than $2000 \mathrm{~m}^{2}$. Bags were left with each household and it was agreed that at harvest the household would record how many bags of maize cobs/sorghum heads were harvested from each plot to the nearest half bag. Yield data was collected in June 2007 after harvesting. From spot checks made in previous seasons, a $50 \mathrm{~kg}$ bag of maize cobs contained $24.0 \mathrm{~kg}$ of grain and a $50 \mathrm{~kg}$ bag of sorghum contained $11.3 \mathrm{~kg}$ of grain (Twomlow et al., 2008b).

\subsection{Analytical framework}

Since the promotion of CF in Zimbabwe can be considered to be at an initial stage, it is rather difficult to measure adoption levels through spontaneous uptake of the technology over time. Therefore, this study sought to estimate the adoption intensity of the different components of CF practices as described in Box 1. The study analyzed the intensity of farmers' adoption of these eight components and determined the factors contributing to variations in intensity levels or the ability to adopt all the CF components. A farmer who has fully adopted all eight components of the CF practices has a score of one. Farmers who have stopped practicing or dis-adopted the technology have a score of zero. The rest of the farmers adopting various components of the CF package have scores between zero and one. It should be noted, however, that the weight of adopting each component can be different given how easy or difficult each component is to apply. However, this is beyond the scope of this present study and must wait for future surveys when farmers have gained much greater experience. A Tobit regression model was used to analyze the influence of different household socioeconomic and farm characteristics on $\mathrm{CF}$ adoption intensity.

In the econometrics literature, three models have been frequently used to analyze technology adoption: (a) linear probability, (b) logistic function (logit), and (c) the normal density function (probit) models (Ayuk, 1997). These models use a binary choice variable as a dependent variable. However, the use of a binary choice variable as a dependent variable may not capture adoption intensity (Baidu-Forson, 1999; Brett, 2004). To overcome this problem the use of a Tobit estimation method (Tobin, 1956; McDonald and Moffit, 1980) has been proposed for analyzing adoption intensity where the dependent variable is continuous with a zero limit. 
Farmers from the 12 surveyed districts differ in the intensity of different $\mathrm{CF}$ practices adopted. The dependent variable $Y$ is derived from a probability that a household will adopt all or any combination of the eight standard CF components. Therefore, a direct application of the Tobit estimation sufficiently provides the needed information on adoption probability and intensity of use of CF technologies.

Farmers' adoption decisions on improved technologies are assumed to be based upon utility maximization (Rahm and Huffman, 1984). Letting $j=1$ for a new improved technology and $j=2$ for the old technology, $U\left(M_{j i}, A_{j i}\right)$ gives the non-observable underlying utility function, which ranks the preference of the $i$ th farmer. This implies that the utility derivable from the conservation farming technology depends on $M$, which is a vector of farm and farmer specific attributes of the adopter and $A$, which is a vector of the attributes associated with the technology. Although the utility function is unobserved, the relation between the utility derivable from a $j$ th technology is postulated to be a function of the vector of observed farm, farmer, technology specific characteristics (e.g. labor demand, land intensification, yield, etc.) and a disturbance term having a zero mean:

$U_{j i}=x_{j} F_{j}\left(M_{i}, A_{i}\right)+e_{j i} \quad j=1,2 ; \quad I=1,2, \ldots, n$.

As the utilities $U_{j i}$ are random, the $i$ th farmer will select the alternative $j=1$, if $U_{1 i}>U_{2 i}$ or if the non-observable (latent) random variable $I=U_{1 i}-U_{2 i}>0$. The probability that $Y_{i}$ equal one (i.e., that the farmer adopts an improved technology is a function of the independent variables:

$$
\begin{aligned}
P_{i} & =P_{r}\left(Y_{i}=1\right)=P_{r}\left(U_{1 i}>U_{2 i}\right) \\
& =P_{r}\left[x_{1} F_{i}\left(M_{i}, A_{i}\right)+e_{l i}>x_{2} F_{i}\left(M_{i}, A_{i}\right)+e_{2 i}\right] \\
& =P_{r}\left[e_{l i}-e_{2 l}>F_{i}\left(M_{i}, A_{i}\right)\left(x_{2}-x_{i}\right]\right. \\
& =P_{r}\left(\mu_{i}>-F_{i}\left(M_{i}, A_{i}\right) \beta\right) \\
& =F_{i}\left(X_{i} \beta\right)
\end{aligned}
$$

where $X$ is the $n \times k$ matrix of the explanatory variables and, $\beta$ is a $k$ $\times 1$ vector of parameters to be estimated, $\operatorname{Pr}($.) is a probability function, $\mu_{i}$ is a random error term and $F\left(X_{i} \beta\right)$ is the cumulative distribution function for, $\mu_{i}$ evaluated at $X_{i} \beta$. The probability that a farmer will adopt conservation farming technology is a function of the vector of explanatory variables and of the unknown parameters and error term. Eq. (2) cannot be estimated directly without knowing the form of $F$. It is the distribution of $\mu_{i}$ that determines the distribution of $F$. If $\mu_{i}$ is normal, $F$ will have a cumulative distribution (Rahm and Huffman, 1984). The functional form of $F$ is specified with a Probit/ Tobit model, where $\mu_{i}$ is an independent and normally distributed error term with zero mean and constant variance $\sigma^{2}$

$$
\begin{aligned}
Y_{i} & =X_{i} \beta \quad \text { if } I=X_{i} \beta+\mu_{i}>T \text { (Adoption) } \\
& =O \text { if } I=X_{i} \beta+\mu_{i}<T \text { (Non-Adoption) }
\end{aligned}
$$

where

$Y_{i}$, Probability of adopting (and intensity of use) of the conservation farming technology;

$I$, non-observed latent variable (index) reflecting the combined effect of $X$ factors that influence technology adoption;

$T$, non-observed threshold level.

Based on the procedures of multivariate Probit analysis the following equations examine the factors influencing the adoption of conservation farming technologies

$$
I=\beta_{0}+\beta_{1} X_{1}+\cdots+\beta_{n} X_{n}
$$$$
\text { and } Y=g(I)
$$

where

$$
\begin{aligned}
& Y=1 \text { if } I \geqslant T \\
& Y=0 \text { if } I \leqslant T .
\end{aligned}
$$

Therefore, the Tobit Model measures not only the probability that a farmer will adopt conservation farming technology, but also the intensity of use of the technology once adopted.

\subsection{Factors hypothesized to influence adoption intensity of $C F$}

The socioeconomic factors that influenced the intensity of the CF component of adoption included both farmer and farm characteristics. Feder et al. (1985) presented factors that, in theory, can affect adoption of new farm technologies. These include availability of credit, limited access to information, risk aversion, inadequate incentives, farm tenure arrangements, insufficient investment in human capital, inadequate farm size, labor constraints, and unreliable and insufficient supply of complementary inputs. Korsching and Nowak (1983) identified attitudes to risk, institutional contacts, and farm size as having a significant bearing

\begin{tabular}{|c|c|c|c|}
\hline $\begin{array}{l}\text { Independent } \\
\text { variables }\end{array}$ & Measure & $\mathrm{H}_{0}$ sign & Rationale \\
\hline Gender & $1=$ Male, $0=$ female & + & Female farmers tend to have labor constraints and will miss some of the components of $\mathrm{CF}$ \\
\hline Age & Years & + & Older farmers with better farm experience are more likely to practice all CF techniques \\
\hline Farming experience & Years & + & Farmers' experience increases the likelihood of understanding the benefits of CF \\
\hline Labor availability & Number of fulltime family labor & + & Availability of labor increases the ability to adhere to all components of CF practices \\
\hline Draft access & $1=$ Yes, $0=$ no & - & Farmers with draft power access are likely to use conventional farm plow tillage practice \\
\hline Illness or death & $1=$ Yes, $0=$ no & - & HIV/AIDS impact negatively on the intensity of CF adoption \\
\hline Extension access & $\begin{array}{l}\text { Number of meetings per growing } \\
\text { season }\end{array}$ & + & Extension services increase information on improved performance of $\mathrm{CF}$ \\
\hline NGO promoting $\mathrm{CF}$ & $\begin{array}{l}1=\text { Promoted by NGO, } 0=\text { no NGO } \\
\text { promotion }\end{array}$ & + & $\begin{array}{l}\text { Spontaneous adopters lacked some technical information and inputs to practice of } \\
\text { components of CF }\end{array}$ \\
\hline CF plot size & $\mathrm{m}^{2}$ & + & $\begin{array}{l}\text { Farmers realizing significant benefits from } \mathrm{CF} \text { have increased } \mathrm{CF} \text { plot sizes and tend to practice } \\
\text { most } \mathrm{CF} \text { techniques }\end{array}$ \\
\hline Experience with CF & $1=2 \mathrm{nd}+$ year, $0=1$ st year & + & $\begin{array}{l}\text { Farmers that have practiced } \mathrm{CF} \text { in the past have a better understanding of benefits of the } \\
\text { technology. }\end{array}$ \\
\hline Rainfall region & $1=$ High rainfall, $0=$ low rainfall & + & Farmers in high rainfall regions practice most components of $\mathrm{CF}$ \\
\hline
\end{tabular}
on decisions by farmers to adopt CF practices. These factors in literature have been classified as personal, physical, institutional and socioeconomic (Ervin and Ervin, 1982; Feder et al., 1985; Shortle and Maranowski, 1986; Napier et al., 1991; Sheikh et al., 2003), which form the majority of this article. These characteristics are listed in Table 2 along with hypotheses on how each characteristic might affect the adoption of CF.

\section{Table 2}

Hypothesized determinants of adoption of CF techniques by vulnerable households in Zimbabwe, 2007. 
Characteristics of the household head such as age and farming experience imply farming knowledge gained over time and are important in evaluating technology information (Feder et al., 1985; Belknap and Saupe, 1988). Older farmers are expected to use their farming experience to decide to adopt the new technology. Family labor availability may influence adoption of most CF components. Farmers who have recent experience with HIV/AIDS are more likely to reduce the intensity of CF practices they adopt based on their access to labor access and resources.

NGO and other institutional support will facilitate farmers' initial exposure to $\mathrm{CF}$ techniques. Farmers exhibit reluctance to adopt technologies that expose the farm enterprise to greater risks and must also be convinced that technical change will indeed bring about a greater reward than existing practices (Napier et al., 1991). Also, farmers located in high potential rainfall regions, with better chances of increased crop production, tend to be less risk averse and are likely to try new cropping techniques. But, wealthier farmers or farmers with access to draft power may be reluctant to practice most components of CF as they can opt for a conventional draft animal tillage system. Also, farmers with access to draft power may give priority to reserving crop residue for livestock feed rather than preserving for use as mulch on CF plots. Although the promoting agent initially determines the plot size, farmers subsequently change the size of their $\mathrm{CF}$ plots in response to observed productivity gains from the technology and possibly the need to intensify farm production. Given that the sample selected households targeted by NGOs are poor, the issue of resource access to plot size is not considered to be significant in the model.

\subsection{Profitability analysis}

The study employed an enterprise budget analysis to assess the viability of adopting CF compared to the conventional animal draft tillage practice. Data used in the analysis were collected from field measurements of crop yields, farmer interviews, focus group discussions, and secondary data that included input prices of seed and fertilizer, and product prices of maize grain and stover. A sensitivity analysis was carried out to assess the changes in profitability of CF practices under different agro-ecological regions.

\section{Results and discussion}

\subsection{Household characterization}

Table 3 provides an overall summary of 232 households interviewed by Natural Region. At least two-thirds of the households are female-headed across all the agro-ecological regions. This is substantially higher than the $20-30 \%$ of female-headed households reported for more general surveys across the country (Ahmed et al., 1997; Twomlow and Ncube, 2001; Mazvimavi, 2004), which suggests some success in targeting the vulnerable households in each district by the NGOs. The average age of the household head ranges from 45 to 50 years with farmers in higher rainfall regions having more years of general farming experience. The most experienced and least resource constrained CF farmers were also located in the higher rainfall areas of the northern Zimbabwe (Table 1) where one church-based organization had been promoting CF to its members since the late 1990s.

Ninety percent of households interviewed were actively practicing CF on part of their farm during the 2006/07 cropping season. At least $73 \%$ of the farmers interviewed had received technical support from NGOs in the past 3 years monitored. The impact of HIV/ AIDS on a household's ability to try CF was investigated and illness and death were used as proxy for the pandemic. Close to half of the households interviewed had a chronically ill household member, but fewer than $10 \%$ of all respondents had experienced a death in the 12 months prior to the interview period. HIV/AIDS is assumed to be a major constraint to agricultural production as household labor access is shared between looking after the sick or young orphans and farm activities.

In the $2006 / 07$ season, at least $40 \%$ of the respondents received seed as well as basal and topdressing fertilizers from NGOs. However, there were some major differences between the Natural Regions. NGOs operating in Natural Region II tended to supply more basal and topdressing fertilizer than NGOs operating in Natural Regions III, IV, and V. In fact, fewer than $46 \%$ of respondents in the drier areas received basal fertilizer from NGOs. This was in contrast to Natural Region II where NGOs provided more than $75 \%$ of the interviewed farmers with basal fertilizers. CF farmers in Natural Region II had larger plot sizes, averaging $2261 \mathrm{~m}^{2}$, compared to $2123 \mathrm{~m}^{2}$ in Natural Regions IV and V. The response in increased plot sizes corresponds to the farmers' experience with CF practices.

\subsection{Adoption of different components of the CF package}

Farmers tend to disassemble technology packages and adopt the most relevant parts initially, followed by additional components over time (Byerlee and Hesse de Polanco, 1986). This was particularly the case with CF promoted under the PRP, where households with varying resource endowments were targeted. There were many variations in CF components that were being practiced across different districts.

Table 3

Typical household characteristics by agro-ecological locations for 232 households surveyed across 12 districts in Zimbabwe in April 2007.

\begin{tabular}{|c|c|c|c|c|}
\hline \multirow[t]{2}{*}{ Variables } & \multirow[t]{2}{*}{ Description } & \multicolumn{3}{|c|}{ Natural region } \\
\hline & & II & III & $\mathrm{IV} / \mathrm{V}$ \\
\hline Number of respondents & & 40 & 54 & 138 \\
\hline \multirow{2}{*}{ Gender of household head } & Male (\%) & 37.5 & 35.2 & 32.1 \\
\hline & Female (\%) & 72.5 & 64.8 & 67.9 \\
\hline Age of household head & Years & 45.2 & 44.7 & 49.5 \\
\hline Illness & Presence of chronically ill household member (\%) & 47.5 & 48.1 & 38.7 \\
\hline Death & Experienced death in the household in past 12 months (\%) & 5.0 & 9.3 & 6.6 \\
\hline Farming experience & Years & 30.4 & 21.6 & 22.7 \\
\hline \multirow[t]{2}{*}{ CF experience } & First time (\%) & 22.5 & 24.1 & 42.3 \\
\hline & At least two seasons (\%) & 77.5 & 75.9 & 57.7 \\
\hline Labor & Mean adult family labor & 1.00 & 1.02 & 1.07 \\
\hline Draft access & With draft power (\%) & 40.0 & 40.7 & 48.9 \\
\hline NGO seed & Have access (\%) & 87.5 & 59.3 & 60.6 \\
\hline NGO basal fertilizer & Have access (\%) & 77.5 & 46.3 & 43.8 \\
\hline NGO topdressing & Have access (\%) & 85.0 & 72.2 & 59.1 \\
\hline Extension access & Number of meetings/training sessions per season & 8.0 & 7.0 & 4.5 \\
\hline NGO promoting CF & Access to NGO support (\%) & 95.0 & 85.2 & 73.0 \\
\hline CF plot size & Area $\left(\mathrm{m}^{2}\right)$ & 2261 & 2168 & 2123 \\
\hline
\end{tabular}


Table 4

Proportion of respondents practicing components of CF (\%) in April 2007 in Zimbabwe.

\begin{tabular}{lccl}
\hline Techniques & \multicolumn{3}{c}{ Cropping season $(n=232)$} \\
\cline { 2 - 4 } & $2004 / 05$ & $2005 / 06$ & $2006 / 07$ \\
\hline Winter weeding & 51.1 & 87.2 & 74.5 \\
Application of crop residues & 39.6 & 75.0 & 68.8 \\
Digging planting basins & 100.0 & 96.0 & 90.0 \\
Application of manure & 78.0 & 82.0 & 70.0 \\
Application of basal inorganic fertilizer & 66.7 & 68.8 & 43.8 \\
Application of topdressing & 90.0 & 92.0 & 74.0 \\
Timely weeding & 94.0 & 96.0 & 76.0 \\
Crop rotation & 7.5 & 30.0 & 25.0 \\
\hline
\end{tabular}

Table 5

Estimated Tobit model for factors influencing adoption intensity of CF for 232 households surveyed across 12 districts in Zimbabwe, 2007.

\begin{tabular}{lclc}
\hline Variable & Coefficient estimate & Standard error & Asymptotic $t$-ratio \\
\hline Constant & 0.095 & 0.065 & 1.470 \\
GENDER & 0.046 & 0.029 & $1.641^{*}$ \\
AGE & 0.0003 & 0.001 & 0.244 \\
FARMEXP & 0.00001 & 0.0001 & 0.083 \\
LABOR & 0.032 & 0.033 & 0.991 \\
ILLDEATH & -0.007 & 0.028 & -0.240 \\
DRAFT & 0.037 & 0.028 & 1.373 \\
EXTN & 0.018 & 0.004 & $4.831^{* *}$ \\
NGO & 0.259 & 0.034 & $7.437^{* *}$ \\
PLOTSIZ & 0.065 & 0.020 & $3.202^{* *}$ \\
CFEXPER & 0.044 & 0.028 & $1.567^{*}$ \\
RAINFAL & 0.152 & 0.029 & $5.209^{* *}$ \\
\hline
\end{tabular}

Log likelihood function $=-18.987$.

* Significant at $10 \%$ level.

* Significant at $1 \%$ level.
Survey results show that $80 \%$ of the respondents continued to maintain the same field and planting stations from one season to the next. Farmers are encouraged to maintain the same plot and planting stations each year to favor an improvement in soil physical and chemical properties and facilitate re-establishment of the basins in subsequent seasons. However, $15 \%$ of the respondents changed planting stations and $5 \%$ of households changed the field in the second season. Farmers cited poor yields in the previous season, soil conditions that prevented re-establishment, pest outbreak, and lack of stover as the reasons to change planting stations (Mazvimavi et al., 2008). In fact, in the first year, some farmers tried the new technology on a relatively poor field so as to limit the risk of food production shortfalls by maintaining conventional farm practice on soils of better quality.

Apart from digging the planting basins, the following components were practiced by at least $70 \%$ of the interviewed farmers: manure application, topdressing and timely post-planting weeding (Table 4). The least implemented components were: crop residue application, basal fertilizer application and crop rotation. The practice of winter weeding has been limited, particularly in the first year of adoption, partly because some farmers joined the program late in the season. Less than $30 \%$ of farmers practiced any form of crop rotation in the past three cropping seasons and the reasons cited included: that this was their first year of practice, they had limited access to legume seed, and some were not aware of the need to rotate crops.

There has been a significant drop in the numbers of farmers applying basal fertilizer and performing timely weeding. This change in adoption patterns is attributed primarily to a decline in agency support; in the early years NGOs provided free inputs and technical partners closely monitored crop management prac-

Table 6

Farm enterprise budget analysis for CF and conventional farm practices for the 2006/07 cropping season in Zimbabwe.

\begin{tabular}{|c|c|c|c|c|c|c|c|c|c|c|}
\hline \multirow[t]{3}{*}{ Item } & \multirow[t]{3}{*}{ Unit } & \multirow[t]{3}{*}{ Price/unit } & \multicolumn{4}{|c|}{ Conservation farming } & \multicolumn{4}{|c|}{ Farmer practice } \\
\hline & & & \multicolumn{2}{|l|}{ First year } & \multicolumn{2}{|c|}{ Second + year } & \multicolumn{2}{|c|}{ No fertilizer } & \multicolumn{2}{|c|}{ With fertilizer } \\
\hline & & & Quantity & Cost (\$USD) & Quantity & Cost (\$USD) & Quantity & Cost (\$USD) & Quantity & Cost (\$USD) \\
\hline \multicolumn{11}{|l|}{ A. Revenue } \\
\hline Maize grain & $\mathrm{kg}$ & 0.4 & 1520.00 & 608.00 & 1780.00 & 712.00 & 368.80 & 147.52 & 400.00 & 160.00 \\
\hline Stover & $\mathrm{kg}$ & 0.12 & 0.00 & 0.00 & 0.00 & 0.00 & 129.08 & 15.49 & 140.00 & 16.80 \\
\hline Total Revenue & & & & 608.00 & & 712.00 & & 163.01 & & 176.80 \\
\hline \multicolumn{11}{|l|}{ B. Variable costs } \\
\hline \multicolumn{11}{|l|}{ B1. Inputs } \\
\hline Maize seed & $\mathrm{kg}$ & 0.47 & 20.00 & 9.40 & 20.00 & 9.40 & 20.00 & 9.40 & 20.00 & 9.40 \\
\hline Basal fertilizer & $\mathrm{kg}$ & 0.33 & 0.00 & 0.00 & 92.50 & 30.53 & 0.00 & 0.00 & 0.00 & 0.00 \\
\hline Topdressing & $\mathrm{kg}$ & 0.35 & 83.30 & 29.16 & 83.30 & 29.16 & 0.00 & 0.00 & 83.30 & 29.16 \\
\hline Plowing services & ha & 22 & & 0.00 & & & 1.00 & 22.00 & 1.00 & 22.00 \\
\hline Total inputs & & & & 38.56 & & 69.08 & & 31.40 & & 60.56 \\
\hline \multicolumn{11}{|l|}{ B2. Labor } \\
\hline Winter weeding & day & 0.88 & 0.00 & 0.00 & 13.00 & 11.44 & 0.00 & 0.00 & 0.00 & 0.00 \\
\hline Winter plowing & day & 0.88 & 0.00 & 0.00 & 0.00 & 0.00 & 7.59 & 6.68 & 7.59 & 6.68 \\
\hline Summer plowing & day & 0.88 & 0.00 & 0.00 & 0.00 & 0.00 & 7.50 & 6.60 & 7.50 & 6.60 \\
\hline Establishing basins & day & 0.88 & 27.63 & 24.31 & 21.08 & 18.55 & 0.00 & 0.00 & 0.00 & 0.00 \\
\hline Residue placement & day & 0.88 & 0.00 & 0.00 & 12.90 & 11.35 & 0.00 & 0.00 & 0.00 & 0.00 \\
\hline Manure placement & day & 0.88 & 8.57 & 7.54 & 0.00 & 0.00 & 9.90 & 8.71 & 9.90 & 8.71 \\
\hline Planting & day & 0.88 & 6.00 & 5.28 & 7.07 & 6.22 & 4.38 & 3.85 & 4.38 & 3.85 \\
\hline Basal application & day & 0.88 & 0.00 & 0.00 & 7.98 & 7.02 & 0.00 & 0.00 & 0.00 & 0.00 \\
\hline Top dressing & day & 0.88 & 9.09 & 8.00 & 7.87 & 6.92 & 0.00 & 0.00 & 8.00 & 7.04 \\
\hline 1st Post-planting weeding & day & 0.88 & 23.38 & 20.57 & 19.25 & 16.94 & 13.75 & 12.10 & 13.75 & 12.10 \\
\hline 2nd Post-planting weeding & day & 0.88 & 15.38 & 13.53 & 14.69 & 12.93 & 11.88 & 10.45 & 11.88 & 10.45 \\
\hline 3rd Post-planting weeding & day & 0.88 & 9.38 & 8.25 & 9.00 & 7.92 & 0.00 & 0.00 & 0.00 & 0.00 \\
\hline Harvesting grain & day & 0.88 & 9.78 & 8.61 & 9.40 & 8.27 & 14.34 & 12.62 & 14.34 & 12.62 \\
\hline Total labor & & & 109.19 & 96.09 & 122.23 & 107.57 & 69.33 & 61.01 & 77.33 & 68.05 \\
\hline Total variable costs & & & & 134.64 & & 176.65 & & 92.41 & & 128.61 \\
\hline \multicolumn{11}{|l|}{ C. Returns } \\
\hline Gross margin & US\$/ha & & & 473.36 & & 535.35 & & 70.60 & & 48.19 \\
\hline Cost per kg & US\$/kg & & & 0.09 & & 0.10 & & 0.25 & & 0.32 \\
\hline Returns to labor & US\$/day & & & 5.22 & & 5.26 & & 1.90 & & 1.50 \\
\hline Labor productivity & kg/day & & & 13.92 & & 14.56 & & 5.32 & & 5.17 \\
\hline
\end{tabular}


tices. In addition, spontaneous adopters, who did not receive support from NGOs and have been increasing over the years, may have influenced this pattern.

\subsection{Estimated Tobit model}

Table 5 summarizes the results of the Tobit Model analysis and shows that the male-headed households (GENDER) were more likely to adopt most of the eight components of the CF package. Age (AGE) and farming experience (FARMEXP) were not important factors in deciding which CF practices to adopt. In other studies, the effect of age on adoption of CF technologies has been mixed. A study on the adoption of soil conservation in uplands in the Philippines showed that age influenced adoption decisions of contour hedgerows both positively and negatively in Cebu and Claveria, respectively (Lapar and Pandey, 1999). Baidu-Forson (1999) concluded that age negatively influenced the adoption of land enhancing technology in the Sahel. In this analysis age effect could have been influenced by the changing life cycle of the farmer with time, and the effect on adoption of CF practices. As farmers grow older, they become more skillful, through learning by doing. But this trend attenuates as they reach middle age and their physical strength begins to decline. Also, with age farmers become more risk averse and less willing to adopt new farming technologies. Some studies have proposed to include a quadratic function to the age variable in order to capture the effect of changing life cycle of the farmer through time (Mazvimavi, 2004). However, there is a positive relationship between experience (CFEXPER) with CF practice and the intensity of adopting different components of the technology. The regression results suggest that the longer a household practices $C F$, the more likely it is to take up all eight components of the CF package.

Household labor availability (LABOR) and impacts of HIV/AIDS (ILLDEATH) do not appear to limit the uptake of the CF package. It can been debated that with HIV/AIDS some households bring in new members which increases labor supply, for example taking in orphans, whereas in some instances, households suffer severe losses on labor with chronic illness and death of family members. However, this interaction is not taken into account in this study. This justifies current NGO initiatives to promote CF to the more vulnerable households in a community as a means of combating food insecurity. As expected, extension access (EXTN) and NGO support (NGO) significantly influenced adoption of different components of CF. Where government extension officers have been working closely with NGO staff in promoting the technology, they have become an important source of backup technical support.
CF adopters with larger plot sizes (PLOTSIZ) were also likely to practice more components of CF. As plot size increased, the likelihood of implementing more of the package increased, as farmers responded positively to yield gains. The results are supported by similar studies on the effect of farm size and technology adoption, where Shortle and Maranowski (1986), Jamnick and Klindt (1985) and Lee and Stewart (1993) have all concluded that the bigger the plot size, the greater the chances of CA being fully adopted.

The rainfall pattern is included in the study to capture spatial variability in CF adoption. Farmers in high rainfall areas (RAINFAL) implemented more $\mathrm{CF}$ components than those in low-rainfall areas. A portion of the interviewed farmers in the high rainfall areas had longer experience with $\mathrm{CF}$, which is by itself a contributing factor to the intensity of adopting different CF components. The adoption patterns by agro-ecological regions seem to contrast results from a study in Zambia where Haggblade and Tembo (2003) concluded that the highest adoption rates of CF using hand-hoe basins occurred in low and scattered rainfall regions. In Zimbabwe, farmers in high rainfall areas had more years of experience with CF practice, where a church-based organization had initially promoted the technology (Mazvimavi et al., 2008) and these farmers tend to increase adoption intensity of the recommended CF components.

\subsection{Profitability analysis of CF practices}

A profitability analysis was carried out based on maize enterprise because it is the most common crop under CF practice in Zimbabwe. Farmers adopting CF for the first time or those with experience (second + year) achieved higher maize grain yields than those practicing conventional farm practices in the 2006/07 cropping season, even with the use of chemical fertilizer (Table 6). First-year practitioners obtained an average maize yield of $1520 \mathrm{~kg} \mathrm{ha}{ }^{-1}$, compared to $368 \mathrm{~kg} \mathrm{ha}^{-1}$ of maize grain realized from their conventionally managed plots, with no fertilizer application. Where fertilizer was applied to conventional farm practice, the control, yield gains were marginally higher, but not adequate to compare with CF plots. Therefore, yield gains achieved with $\mathrm{CF}$ practices represented close to $300 \%$ increase, in a season considered a drought year for Zimbabwe (FAO, 2007). For the more experienced farmers the cumulative effects of maintaining the same planting positions can be seen, with an additional $250 \mathrm{~kg} \mathrm{ha}^{-1}$ maize grain being realized. The more farmers have experience with $\mathrm{CF}$ the more efficient they become in managing most of the recommended components of the technology, thereby achieving superior

Table 7

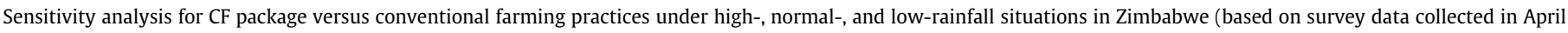
2007).

\begin{tabular}{|c|c|c|c|c|c|}
\hline & & \multicolumn{2}{|c|}{ CF practice } & \multicolumn{2}{|c|}{ Conventional farmer practice } \\
\hline & & First year & Second + year & No fertilizer & With fertilizer \\
\hline \multicolumn{6}{|c|}{ High rainfall (At least $750 \mathrm{~mm}$ per annum) } \\
\hline Maize grain & $\mathrm{kgha}^{-1}$ & 2000.00 & 2650.00 & 678.00 & 1120.00 \\
\hline Gross margin & US\$ ha ${ }^{-1}$ & 654.18 & 866.84 & 196.64 & 357.16 \\
\hline Cost per kg & US\$ $\mathrm{kg}^{-1}$ & 0.07 & 0.07 & 0.15 & 0.12 \\
\hline Returns to labor & US\$ day $^{-1}$ & 6.25 & 7.03 & 3.30 & 4.94 \\
\hline \multicolumn{6}{|c|}{ Normal rainfall (650-800 mm per annum) } \\
\hline Maize grain & $\mathrm{kgha}^{-1}$ & 1750.00 & 2200.00 & 560.00 & 728.00 \\
\hline Gross margin & US\$ha ${ }^{-1}$ & 529.42 & 697.17 & 152.77 & 191.06 \\
\hline Cost per kg & US\$ $\mathrm{kg}^{-1}$ & 0.10 & 0.08 & 0.17 & 0.18 \\
\hline Returns to labor & $\mathrm{US}$ day $^{-1}$ & 5.47 & 6.27 & 3.00 & 3.28 \\
\hline \multicolumn{6}{|c|}{ Low rainfall (450-650 mm per annum) } \\
\hline Maize grain & $\mathrm{kgha}^{-1}$ & 1520.00 & 1780.00 & 368.00 & 400.00 \\
\hline Gross margin & US\$ha ${ }^{-1}$ & 473.36 & 535.35 & 70.60 & 48.19 \\
\hline Cost per kg & US\$ kg-1 & 0.09 & 0.10 & 0.25 & 0.32 \\
\hline Returns to labor & $\mathrm{US}$ day $^{-1}$ & 5.22 & 5.26 & 1.90 & 1.50 \\
\hline
\end{tabular}


yield gains compared to first-year farmers. Only marginal gains of $32 \mathrm{~kg} \mathrm{ha}{ }^{-1}$ were achieved with the use of fertilizer in farmer practice.

First-year farmers spent 109 days ha ${ }^{-1}$ producing maize under $\mathrm{CF}$ compared to the 122 days ha ${ }^{-1}$ spent by more experienced farmers. Experienced farmers were more likely to place crop residues in their plots and apply basal fertilizer than first time CF farmers. This labor requirement for both first time and experienced farmers is significantly higher than conventional farm practice that requires at most 77 days ha $^{-1}$ to produce maize. The difference in labor requirements is primarily due to demands in weed control, fertilizer application, and the management of crop residues. The analysis assumes that under conventional farm practice there is no application of inorganic fertilizer. Manure placement is considered as organic fertilizer application. Application of inorganic fertilizer in low-rainfall areas of Zimbabwe is not common with exceptions when selected farmers receive free fertilizer through relief programs. Farmers practicing CF for the first time had a gross margin five times greater than those earned by farmers using conventional practices. The more experienced conservation farmers earned even a higher gross margin than first-time farmers. These results hold true despite the fact that digging planting basins is labor intensive, requiring at least 21 days ha ${ }^{-1}$ for basin establishment. The results also confirm the higher economic returns from maize production under CF compared to conventional farmer practices.

The budget analysis in Table 6 enabled a sensitivity analysis to be carried out that showed the potential viability of CF across different agro-ecological regions. Maintaining all other production costs constant, CF remain more profitable than conventional farmer practice, even when significant yield gains can be achieved from farmer practice in higher rainfall conditions with fertilizer use (Table 7). This conclusion is in contrast to an initial sensitivity analysis we carried out on a sub-sample of this data set, which suggested that conventional farm practices remain viable under higher rainfall conditions (Mazvimavi and Twomlow, 2008). In higher rainfall conditions experienced $\mathrm{CF}$ farmers can earn a gross margin of US\$866.84 per hectare compared to US\$357.16 per hectare earned by a farmer using chemical fertilizer. The results hold true for other maize production returns. The cost of producing a kilogram of maize is cheaper with CF and earns higher returns to labor than with farmer practice across all agro-ecological regions.

\subsection{Changes in area under $C F$}

On average, farmers are expanding the size of their CF plots across the 12 districts, a possible response to the viability of the new technology being adopted by mostly vulnerable farmers in search of food security. Plot sizes ranged from an average of $1449 \mathrm{~m}^{2}$ in the 2004/05 season to more than $2022 \mathrm{~m}^{2}$ in the 2006/07 season (Table 8). Gokwe South, Nkayi and Hwange districts had farmers with the largest plot sizes in the 2006/07 season. However, farmers were sometimes confused by messages from NGO field staff about the amount of land they should allocate to $\mathrm{CF}$. In some areas the plot size for CF was controlled by the staff of the promoting agency who feared labor constraints of a particular household. However, CF practitioners also made decisions on the area under CF based on the amount of seed they could obtain and the perceived productivity gains.

It is anticipated that farmers will further increase plot sizes as they respond to productivity gains. This will reach a threshold area that is determined by input resource constraints but that is yet to be determined. There were some areas where farmers initially adopted $\mathrm{CF}$ practices through learning from neighbors and when subsequently included by NGOs in the promotion, made changes to their plot sizes. Plot sizes also changed when farmers changed the $\mathrm{CF}$ plot to another location or when facilitating crop rotation.
Table 8

Changes in CF plot sizes across 12 districts of Zimbabwe, 2004/05-2006/07 seasons $\left(\mathrm{m}^{2}\right)$.

\begin{tabular}{lccc}
\hline District & \multicolumn{2}{c}{ Cropping season } & \\
\cline { 2 - 4 } & $2004 / 05$ & $2005 / 06$ & $2006 / 07$ \\
\hline Bindura & 2173 & 1814 & 2143 \\
Chirumhanzu & 361 & 584 & 1047 \\
Chivi & 1000 & 1053 & 1000 \\
Gokwe South & 400 & 1830 & 3074 \\
Hwange & 3575 & 2967 & 3062 \\
Insiza & 1500 & 1686 & 1865 \\
Mangwe & 2282 & 1994 & 1356 \\
Masvingo & 700 & 1239 & 1209 \\
Mt. Darwin & 1725 & 1993 & 2452 \\
Murehwa & 1000 & 969 & 1274 \\
Nkayi & & 1934 & 4616 \\
Nyanga & 1233 & 1312 & 1164 \\
Mean area & $\mathbf{1 4 4 9}$ & $\mathbf{1 6 1 5}$ & $\mathbf{2 0 2 2}$ \\
\hline
\end{tabular}

\subsection{Constraints to CF adoption}

Participants discussed a number of issues associated with adoption of all components of CF practices during the focus group discussions. Below is a summary of the major constraints highlighted by farmers.

\subsubsection{Labor availability}

Throughout the household interviews and focus group discussions farmers expressed concern on numerous activities associated with CF implementation, such as off-season land preparation, multiple weeding sessions, and crop residue management. Despite this, such concerns were not confirmed by the regression model where labor access did not have a significant effect on CF adoption decisions. However, it is expected that the labor demand in $\mathrm{CF}$ practice will decline as farmers gain experience with the technology as illustrated in Table 6. For example, farmers experienced in CF can save at least 5 days of basin establishment time compared to first-year farmers.

Labor for weed control also declines with successive weeding and weed density is lower for plots that have had basins for successive seasons. It is also important to note that in the first year of adopting $\mathrm{CF}$, farmers are unlikely to practice winter weeding and place mulch in the plots. Also, in order to draw strong conclusions and recommendations for $\mathrm{CF}$, it will be important to continue monitoring farmers who have adopted the technology for more than three seasons.

\subsubsection{Crop residue management}

CF plots that are not adequately protected or fenced are likely to be invaded by animals that destroy the basins and graze most of the stover left for mulch (Table 9). A limited number of farmers (5.7\%) placed a higher value on feeding stover to livestock than reserving it for mulching. This not surprising given the targeted nature of the sample population who were predominantly vulnerable and may not accurately reflect the attitudes of the general

Table 9

Vulnerable households' responses for not applying crop residues as mulch in CF plots averaged across 12 districts in Zimbabwe, April $2007(N=232)$.

\begin{tabular}{ll}
\hline Response & $\begin{array}{l}\text { Proportion of respondents } \\
(\%)\end{array}$ \\
\hline Residues eaten by animals & 36.2 \\
First year, did not reserve residues from previous & 43.9 \\
$\quad$ year & 14.2 \\
Residues eaten by termites & 5.7 \\
Reserved residues for stock feed & \\
\hline
\end{tabular}


population. Crop residues can be considered to be exclusive or non-exclusive products based on how they are used for mulching (Erenstein and Cadena-Inguez, 1997; Erenstein, 2003). In a situation where farmers have enclosed fields, crop residues are exclusive products; the person who is not prepared to pay for their use is excluded from using them. In unfenced fields, crop residues are non-exclusive products and it is difficult to exclude users who do not want to pay, particularly when the practice of free grazing is as common as it is in Zimbabwe's smallholder farm sector. Exclusive residue retention may require considerable investment in collecting and transporting the residues and fencing the fields (Table 6 ). Therefore, the value of crop residues can be assumed to be reflected in the costs of fencing the fields and additional labor requirements on collection, transport and management of residues.

The promotion of mulching in CF systems has to be done concurrently with the promotion of improved methods of crop residue harvesting, storage and feeding so that the available quantities can meet the needs of the crop and livestock sub-systems. Also, farmers should be encouraged to establish fencing projects on their own or through farmer groups to protect $C F$ plots from animals. However, this requires community cooperation as farmers not practicing CF may not appreciate the benefits of such projects.

\subsubsection{Crop rotation}

The $\mathrm{CF}$ package requires farmers to rotate cereals with legumes. However, in the majority of cases, this was not possible because of the general shortage of legume seed across the country and the common understanding that legumes should not be planted in the basins but in shallow furrows. However, there were isolated cases where crops were successfully rotated, especially in areas where farmers have been practicing $\mathrm{CF}$ for a longer period than the rest of the survey districts. Another constraint to crop rotation is that staple cereals tend to be given priority over other crops including legumes. This short-term perspective may be a reflection of the target group.

\subsubsection{Institutional factors}

In some areas, NGOs tended to promote CF with limited participation of local extension officers. The Tobit model has shown the effectiveness of institutional support on CF adoption and agrees with the observations made by Derpsch (2005) and Hobbs (2007) those farmers who received continued support from both NGOs and the government extension services tended to intensify adoption of different CF components. Also, NGOs provided free inputs such as basal and topdressing fertilizers that encouraged fertilizer application to basin plots. It is important to have extension agents participate in the promotion of $\mathrm{CF}$ at earlier stages to ensure wider adoption by other farmers not included in the initial promotions by NGO. This is critical at the later stage when NGOs pull out in order to assess how the CF farmers can sustainably practice all the components of the technology.

\subsubsection{Access to inputs}

Input markets influence the adoption of agricultural technologies. Access to NGO seed and fertilizer increased the intensity of $\mathrm{CF}$ adoption. In focus group discussions farmers cited limited input access as a major determinant of plot size. Seed, fertilizer and fencing material shortages in rural retail markets are constraining farmers' initiatives to expand the CF area and protect fields from animals. Basal fertilizer is routinely unavailable, resulting in the use of manure only as a basal fertility dressing. In the absence of NGO provision of agricultural inputs there is need to encourage participation of local retail outlets in providing seeds and fertilizers that are necessary for farmers practicing $\mathrm{CF}$.

\section{Conclusion}

There has been significant expansion in CF practices in Zimbabwe, following promotional efforts by relief agencies aiming to improve food security among vulnerable farmers. Irrespective of earlier concerns on the demand for labor, elderly farmers and households affected by HIV/AIDS are among the adopters of CF. This study purposely sampled farmers known to be practicing CF and known to be targeted by NGOs as being vulnerable to food production shortages. The Tobit model results show that extension access, NGO support, increased plot size and agro-ecological location significantly influences the intensity of adopting different components of CF technology at $1 \%$ level. The significant yield gains realized from adopting CF practices also offset the production costs associated with the technology. This improves viability and provides an incentive for $\mathrm{CF}$ adoption by smallholder farmers in Zimbabwe and potentially elsewhere in SSA. Active support by both NGOs and government change agents through the supply of seed, fertilizer, and training increased the likelihood of CF adoption.

Challenges remain on the adoption of all recommended components of CF practices with no more than $30 \%$ of farmers so far practicing crop rotation. Management of crop residues and access to such inputs as seed and inorganic fertilizers need to be improved for farmers to achieve maximum benefits from the technology.

Relief programs will continue to be an important intervention in support of CF technology uptake working together with the national extension services for as long as the current economic crisis continues in Zimbabwe. However, it is anticipated that the private sector will later actively participate in the provision of necessary agricultural inputs as the economy improves. This support should include improving access to agricultural inputs that are critical to the needs of farmers practicing CF. Subsequent studies will build on this baseline as CF farmers gain more experience and confidence with the technology under the continuing relief and recovery programs.

\section{Acknowledgements}

We wish to thank the farmers and Government of Zimbabwe Extension staff for their enthusiasm and collaboration, and the field staff of the PRP NGOs for their support during field work. We also wish to thank DFID, FAO and ICRISAT for the funding. The opinions expressed in this paper are those of the authors. We are grateful for the very useful comments made by the two reviewers and the Editor in Chief.

\section{References}

Ahmed, M.M., Rohrbach, D.D., Gono, L., Mazhangara, E., Mugwira, L., Masendeke, D.D., Alibaba, S., 1997. Soil Fertility Management in Communal Areas of Zimbabwe: Current Practices, ICRISAT Southern and Eastern Africa Region. Working Paper No. 6, P.O. Box 776, Bulawayo, Zimbabwe.

Ayuk, E.T., 1997. Adoption of agroforestry technology: the case of live hedges in the Central Plateau of Burkina Faso. Agric. Syst. 54 (2), 189-206.

Baidu-Forson, J., 1999. Factors influencing adoption of land-enhancing technology in the Sahel: lessons from a case study in Niger. Agric. Econ. 20 (3), 231-239.

Belknap, J., Saupe, W.E., 1988. Farm family resources and the adoption of no-plow tillage in Western Wisconsin. North Central J. Agric. Econ. 10, 13-23.

Brett, C., 2004. Farm level adoption decisions of soil water management technologies in Semi-Arid Eastern Kenya. In: Contributed Paper Presented at the 48th Annual Conference of the Australian Agricultural and Resource Economics Society, 11-13th February, 2004, Melbourne, Victoria.

Byerlee, D., Hesse de Polanco, E., 1986. Farmers' stepwise adoption of technological packages: evidence from the Mexican Altiplano. Am. J. Agric. Econ. 68 (3), 519527.

Derpsch, R., 2005. The extent of conservation agriculture adoption worldwide: implications and impact. In: Keynote Paper at the 3rd World Congress on Conservation Agriculture. World Agroforestry Center, Nairobi, Kenya.

Erenstein, O., 2003. Smallholder CF in the tropics and sub-tropics: a guide to the development and dissemination of mulching with crop residues and cover crops. Agric. Ecosyst. Environ. 100, 17-37. 
Erenstein, O., Cadena-Inguez, P., 1997. Adoption of Conservation Tillage in a Hillside Maize Production System in Motozintla, Chiapas. CIMMYT.

Ervin, C.A., Ervin, D.E., 1982. Factors affecting the use of soil conservation practices. Land Econ. 58, 79-90.

FAO, 2007. Agricultural Coordinating Working Group. May 2007 Journal. FAO Harare. Available from: <http://www.zimrelief.info>.

Feder, G., Just, R.E., Zilberman, D., 1985. Adoption of agricultural innovations in developing countries: a survey. Econ. Dev. Cult. Change 33 (2), 255-298.

Gowing, J.W., Palmer, M., 2008. Sustainable agricultural development in subSaharan Africa: the case for paradigm shift in land husband. Soil Use Mgt. 24 (1), 92-99.

Haggblade, S., Tembo, G., 2003. Early evidence on CF in Zambia. In: A paper prepared for the International Workshop on "Reconciling Rural Poverty and Resource Conservation: Identifying Relationships and Remedies". Cornell University, Ithaca, New York.

Hobbs, P.R., 2007. Conservation agriculture, what is it and why is it important for future sustainable food production? J. Agric. Sci. 145, 127-137.

Hobbs, P.R., Sayre, K., Gupta, R., 2007. The role of conservation agriculture in sustainable agriculture. Phil. Trans. R. Soc. B 363, 543-555.

Hove, L., Twomlow, S., 2007. Is conservation agriculture an option for vulnerable households in Southern Africa? In: Paper Presented at the Conservation Agriculture for Sustainable Land Management to Improve the Livelihood of People in Dry Areas Workshop, United Nations Food and Agricultural Organization, 7-9 May, 2007. Damascus, Syria.

Jamnick, S.K., Klindt, T.H., 1985. An analysis of 'no-tillage' practice decisions. Department of Agricultural Economics and Rural Sociology, University of Tennessee, USA.

Korsching, P., Nowak, P., 1983. Soil erosion awareness and use of conservation tillage. Water Res. Bulletin 19 (3), 459-462.

Lal, R., 2007. Constraints to adopting no-till farming in developing countries. Soil Tillage Res. 94, 1-3.

Lapar, M.L.A., Pandey, S., 1999. Adoption of soil conservation: the case of the Philippines uplands. Agric. Econ. 21, 241-256.

Lee, L.K., Stewart, W.H., 1993. Land-ownership and the adoption of minimum tillage. Am. J. Agric. Econ. 68, 256-264.

Mando, A., Fatondji, D., Zougmoré, R., Brussaard, L., Bielders, C.L., Martius, C., 2006. Restoring soil fertility in semi-arid West Africa. In: Uphoff, N., Ball, A.S., Fernandez, E., Herren, H., Husson, O., Laing, M., Palm, C., Sanchez, P., Sanginga, N., Thies, J. (Eds.), Biological Approaches to Sustainable Soil Systems. CRC Press, Boca Raton, pp. 271-287 (ISBN: 1574445839).

Mazvimavi, K., 2004. Socioeconomic analysis of efficiency and productivity growth in the resettlement areas of Zimbabwe. A dissertation submitted in partial fulfilment of the requirements for the degree of Doctor of Philosophy. University of Wisconsin-Madison, Wisconsin. p. 210.

Mazvimavi, K., Twomlow, S., 2008. Conservation farming for agricultural relief and development in Zimbabwe. In: Goddard, T., Zoebisch, M.A., Gan, Y.T., Ellis, W., Watson, A., Sombatpanit, S. (Eds.), No-Till Farming Systems. Special Publication No. 3, World Association of Soil and Water Conservation, Bangkok. p. 544, ISBN: 978-974-8391-60-1.

Mazvimavi, K., Twomlow, S., Belder, P., Hove, L., 2008. An Assessment of the Sustainable Uptake of Conservation Farming in Zimbabwe. Global Theme on
Agroecosystems Report No. 39. P.O. Box 776, International Crops Research Institute for the Semi-Arid Tropics, Bulawayo, Zimbabwe. p. 60.

McDonald, J.F., Moffit, R.A., 1980. The uses of Tobit analysis. Rev. Econ. Stat. 62, 318 321.

Napier, T.L., Napier, A.S., Tucker, M.A., 1991. The social, economic and institutional factors affecting adoption of soil conservation practices: Asian experiences. Soil Tillage Res. 20, 365-382.

Protracted Relief Program (PRP), 2005. CF for Vulnerable Households. Guidelines for PRP Partners, No. 1 DFID and ICRISAT. Available from: <www.prpzim.info>.

Rahm, M.R., Huffman, W.E., 1984. The adoption of reduced tillage: the role of human capital and other variables. Am. J. Agric. Econ. November, 405-413.

Rockstrom, J., Hatibu, N., Oweis, T.Y., Wani, S., Barron, J., Bruggeman, A., Farahani, J. Karlberg, L., Qiang, Z., 2007. Managing water in rainfed agriculture. In: CAWMA 2007, Water for Food, Water for Life: A Comprehensive Assessment of Water Management in Agriculture. Earthscan, London (Chapter 8).

Rusike, J., Twomlow, S.J., Freeman, H.A., Heinrich, G.M., 2006. Does farmer participatory research matter for improved soil fertility technology development and dissemination in Southern Africa? Int. J. Agric. Sustain. 4 (3), 176-192.

Sall, S., Norman, D., Featherstone, A.M., 2000. Quantitative assessment of improved rice variety adoption: the farmer's perspective. Agric. Syst. 66 (2), $129-144$

Sheikh, A.D., Rehman, T., Yates, C.M., 2003. Logit models for identifying the factors that influence the uptake of new 'No-Tillage' technologies by farmers in the rice-wheat and the cotton-wheat farming systems of Pakistan's Punjab. Agric. Syst. 75, 79-95.

Shortle, J.S., Maranowski, J.A., 1986. Effect of risk perceptions and other characteristics of farmer and farm operations on the adoption of conservation tillage practices. Department of Agricultural Economics, Pennsylvania State University, USA.

Tobin, J., 1956. Estimation of relationships for limited dependent variables. Econometrica 26, 24-36.

Twomlow, S.J., Ncube, B. (Eds.), 2001. Improving soil management options for women farmers in Malawi and Zimbabwe. In: Proceedings of a Collaborators Workshop on the DFID-Supported Project 'Will Women Farmers Invest in Improving their Soil Fertility Management?' Experimentation in a Risky Environment, 13-15th September, 2000, ICRISAT Bulawayo, Zimbabwe, p. 150 (P.O. Box 776, International Crops Research Institute for the Semi-Arid Tropics, Bulawayo, Zimbabwe).

Twomlow, S.J., Steyn, J.T., du Preez, C.C., 2006. Dryland farming in southern Africa. In: Dryland Agriculture 2nd Edition. Agronomy Monograph No. 23. American Society of Agronomy, Madison, Wisconsin. pp. 769-836 (Chapter 19).

Twomlow, S., Urolov, J.C., Jenrich, M., Oldrieve B., 2008a. Lessons from the field Zimbabwe's Conservation Agriculture Task Force. Journal of SAT Agricultural Research 6 (11pages).

Twomlow, S., Rohrbach, D., Dimes, J., Rusike, J., Mupangwa, W., Ncube, B., Hove, L., Moyo, M., Mashingaidze, N., Mahposa, P., 2008b. Micro-dosing as a pathway to Africa's Green Revolution: evidence from broad-scale on-farm trials. Nutr. Cycl. Agroecosyst, doi:10.1007/s10705-008-9200-4.

Vincent, V., Thomas, R.G., 1960. An agricultural survey of Southern Rhodesia: Part I: agro-ecological survey. Government Printers, Salisbury. 